\title{
Analisis Pengelolaan Piutang Penerimaan Negara Bukan Pajak (PNBP)
}

\author{
Wiwiek Patricia ${ }^{1}$, Bambang Pamungkas ${ }^{2}$ \\ Program Magister Akuntansi, Fakultas Ekonomi dan Bisnis, Universitas Indonesia, Jakarta, Indonesia ${ }^{1 \& 2}$ \\ tresgultom@gmail.com
}

\begin{abstract}
Ministry of Communications and Informatics (Kemkominfo) is one of the largest contributors to Indonesia Government's Non-Tax Revenues, primarily from frequency usage right fees. Kemkominfo owns a substantial amount of payment receivables and challenged by receivables collection. Kemkominfo therefore had established a provision for doubtful accounts however the amount is unusually high. This paper provides a deep dive into how Kemkominfo internally manages its substantial receivable book. A qualitative analysis with a case study approach is applied for the purpose of the analysis. Further, the data collection is conducted via document analysis and employees interview. The results of this study indicate that: (1) Radio Station Licensce (ISR) was given without evaluating relevant key factors which can avoid uncollected receivables happening; (2) there is no measurable target for receivables collection activities; (3) the submission of the write-off of accounts receivable that is not immediately processed causes the value of the receivables presented to be less accurate.
\end{abstract}

Keywords: new public management; non-tax revenue; receivables; management

\begin{abstract}
Abstrak
Kementerian Komunikasi dan Informatika (Kominfo) merupakan salah satu penyumbang terbesar pada Penerimaan Negara Bukan Pajak (PNBP) lainnya terutama dari Biaya Hak Penggunaan Frekuensi Radio, namun Kementerian Kominfo memiliki piutang PNBP dan penyisihan piutang tidak tertagih yang jumlahnya relatif besar. Penelitian ini bertujuan untuk melakukan evaluasi atas pengelolaan piutang Penerimaan Bukan Pajak (PNBP) di lingkungan Kementerian Kominfo. Prosedur pengumpulan data pada penelitian ini adalah dengan melakukan studi dokumen dan wawancara pada pegawai di lingkungan Kementerian. Metode kualitatif dengan pendekatan studi kasus dipilih untuk menjawab permasalahan penelitian. Hasil penelitian ini menunjukkan antara lain: (1) Pada tahap verifikasi Izin Stasiun Radio belum dilakukan evaluasi atas beberapa faktor penting untuk mencegah timbulnya piutang yang bermasalah di kemudian hari; (2) Belum ada target yang terukur atas aktivitas penagihan piutang; (3) Pengajuan penghapusan piutang yang tidak segera diproses setelah menerima penetapan berpotensi menyebabkan nilai piutang yang disajikan kurang akurat.
\end{abstract}

Kata Kunci: new public management; penerimaan negara bukan pajak; piutang; pengelolaan

\section{PENDAHULUAN}

Dalam melaksanakan tugas pemerintahan yang antara lain memberikan pelayanan kepada masyarakat luas dan melaksanakan pembangunan, pemerintah memerlukan dana yang tidak sedikit untuk mencapai target yang direncanakan. Dana tersebut dihimpun dari pendapatan yang diperoleh oleh negara. Pendapatan negara untuk penyelenggaraan pemerintahan bersumber dari penerimaan pajak, Penerimaan Negara Bukan Pajak (PNBP) dan hibah. Sampai dengan saat ini penerimaan negara sebagian besar bersumber dari penerimaan pajak, namun dalam beberapa tahun terakhir kontribusi PNBP dalam penerimaan negara semakin meningkat tiap tahunnya. Laporan Keuangan Pemerintah Pusat tahun 2015-2018 menunjukkan bahwa PNBP telah memberikan sumbangan terhadap total penerimaan negara dengan rata-rata nilai hampir sebesar 20\%. PNBP sendiri terdiri dari sektor Sumber Daya Alam, bagian laba Badan Usaha Milik Negara (BUMN), pendapatan Badan Layanan Umum (BLU), dan PNBP lainnya. Persentase terbesar PNBP terbesar berasal dari sumber daya alam dan kedua terbesar berasal dari PNBP lainnya yaitu rata-rata sebesar $36 \%$. Kementerian 
Komunikasi dan Informatika (Kominfo) merupakan salah satu penyumbang terbesar pada PNBP lainnya, yang antara lain bersumber dari Biaya Hak Penggunaan Frekuensi Radio (BHP Frekuensi Radio) dengan pengelolaannya di bawah Direktorat Jenderal Sumber Daya dan Perangkat Pos dan Informatika (SDPPI).

Sejak pemerintah melaksanakan penerapan akuntansi berbasis akrual, pendapatan diakui pada saat timbulnya hak atas pendapatan tersebut. Apabila terdapat tunggakan pungutan pendapatan dan pemberian pinjaman serta transaksi lainnya yang menimbulkan hak tagih pemerintah pada tanggal laporan keuangan, harus dicatat sebagai penambahan aset pemerintah berupa piutang. PNBP memiliki peran yang sangat penting dalam memberikan dukungan untuk pembiayaan nasional, sehingga pengelolaan pendapatan dan piutang PNBP ini harus dilaksanakan secara serius dan optimal

Masalah yang diangkat pada penelitian ini adalah mengapa piutang dan penyisihan piutang tidak tertagih PNBP pada Kementerian Kominfo memiliki nilai yang tinggi dan mengalami kecenderungan meningkat. Untuk itu peneliti perlu mempelajari bagaimana siklus pengelolaan dan pencatatan piutang PNBP pada Kementerian Kominfo pada tahun 2015 samapi dengan tahun 2018. Laporan Keuangan Kementerian Kominfo tahun 2015 sampai dengan 2018 menunjukkan bahwa Kementerian memiliki piutang Bukan Pajak yang relatif cukup besar namun juga memiliki Penyisihan Piutang Tidak Tertagih Piutang Bukan Pajak yang jumlahnya besar pula. Porsi terbesar dari Piutang Bukan Pajak pada Kementerian Kominfo adalah Piutang BHP Frekuensi, dan permasalahan mengenai hal ini juga menjadi perhatian dari Badan Pemeriksa Keuangan Republik Indonesia (BPK RI), dimana pada Laporan Hasil Pemeriksaan atas Kepatuhan Terhadap Peraturan Perundang-undangan Tahun 2016 dan 2017, BPK memasukkan pengelolaan piutang macet atas BHP Frekuensi dalam temuannya. Sementara piutang tersebut merupakan potensi penerimaan bagi negara, sehingga perlu diteliti mengenai efektivitas pengelolaan piutang tersebut. Pengelolaan piutang harus dilakukan dengan efektif sehingga Piutang Negara tertagih secara tepat waktu, akuntabilitas penyelenggaraan tugas pemerintah tercapai dan Laporan Keuangan Pemerintah dapat tersaji secara akuntabel.

Atas dasar permasalahan tersebut, penelitian ini bertujuan untuk memahami dan melakukan analisis pengelolaan piutang PNBP pada Kementerian Kominfo untuk mengetahui mengapa piutang dan penyisihan piutang tidak tertagih memiliki nilai yang tinggi. Peneliti memilih Kementerian Kominfo sebagai subjek karena Kementerian Kominfo merupakan salah satu penghasil terbesar atas PNBP lainnya dan sampai saat ini belum banyak penelitian yang membahas mengenai piutang PNBP pada Kementerian. Penelitian ini terbatas hanya pada pengelolaan piutang PNBP BHP Frekuensi Radio saja.

Berdasarkan Ellet (2007), manfaat dari penelitian ini antara lain adalah menjadi bahan evaluasi dalam pengelolaan piutang PNBP di lingkungan Kementerian Kominfo. Dari evaluasi tersebut diharapkan di waktu yang akan datang pelaksanaan pengelolaan piutang PNBP terutama BHP Frekuensi Radio dapat dilaksanakan lebih baik lagi dan laporan keuangan menjadi lebih akuntabel, terutama dapat membantu dalam mengamankan kekayaan negara.

Tinjauan atas penelitian terdahulu juga dilakukan pada penelitian ini, diantaranya adalah penelitian atas pengelolaan piutang pada berbagai sektor industri oleh Nebugri \& Senzu (2017). Penelitian tersebut menemukan beberapa faktor yang mempengaruhi pengelolaan piutang, antara lain adalah kurangnya kebijakan kredit yang formal pada perusahaan, kebanyakan perusahaan tidak memiliki fungsi pengendalian kredit, dan mayoritas perusahaan masih menggunakan sistem invoicing manual. 
Meriam et al. (2017) meneliti alat pengukuran kinerja manajemen piutang dan faktor-faktor yang mempengaruhi kinerja piutang. Dari hasil penelitian tersebut disimpulkan bahwa perilaku pembayaran dari pelanggan merupakan penyebab utama dari tingginya piutang yang telah lewat jatuh tempo, selain juga karena adanya keterlambatan pengembalian nota pengiriman. Penelitian oleh Taroreh et al. (2016) menemukan bahwa tidak adanya tindakan oleh perusahaan dalam menangani piutang tidak tertagih menyebabkan banyaknya penagihan yang tidak berjalan lancar. Ketiga penelitian terdahulu terkait piutang dan manajemen piutang yang dilakukan pada sektor swasta atau komersial, sementara penelitian ini membahas mengenai piutang pada sektor pemerintahan.

Piutang menurut Donald E. Kieso PhD, Jerry J. Weygandt PhD, \& Terry D. Warfield (2018) adalah klaim terhadap pelanggan dan lainnya atas uang, barang dan jasa. Piutang Negara menurut Republik Indonesia (2004) tentang Perbendaharaan Negara dinyatakan sebagai jumlah uang yang harus dibayar kepada Pemerintah yang timbul dari perjanjian atau dari peraturan perundangundangan yang berlaku atau akibat lainnya yang sah. Dalam kerangka konseptual dalam Pemerintah Republik Indonesia (2010) tentang Standar Akuntansi Pemerintahan, piutang masuk dalam kategori aset lancar bersama dengan kas dan setara kas, investasi jangka pendek dan persediaan.

Piutang merupakan bagian dari siklus pendapatan. Menurut Romney \& Steinbart (2015) siklus pendapatan merupakan aktivitas bisnis dan pengolahan informasi yang berulang terkait penyediaan barang dan jasa untuk konsumen dan mengumpulkan kas atas pembayaran dari penjualan tersebut. Siklus aktivitas pendapatan dibagi menjadi empat, yaitu: entry order penjualan, pengiriman, penagihan dan penerimaan kas. Siklus penjualan dan penerimaan kas menurut Arens, Elder, \& Beasley (2012) terdiri dari lima kelas transaksi, yaitu penjualan baik secara kas maupun secara kredit, penerimaan kas, retur penjualan, penghapusan piutang tidak tertagih, dan pencadangan piutang tidak tertagih. Siklus ini diawali dari permintaan oleh pelanggan dan berakhir dengan konversi dari barang atau jasa menjadi piutang, dan akhirnya menjadi kas. Prinsip dalam mengakui pendapatan adalah ketika perusahaan memenuhi kewajibannya dengan mengalihkan barang atau jasa kepada pelanggan dan pelanggan memperoleh kendali atas barang atau jasa tersebut. Ketika terjadi perpindahan atas kendali terjadi, perusahaan harus mengakui piutang dan pendapatan Donald E. Kieso $\mathrm{PhD}$ et al. (2018). Indikator yang menentukan bahwa telah terjadi perpindahan kontrol atas barang atau jasa dan pelanggan telah menerimanya adalah saat perusahaan memiliki hak atas pembayaran dari pelanggan, perusahaan telah memindahkan legal title kepada pelanggan, perusahaan telah memindahkan kepemilikan fisik atas barang, perusahaan tidak lagi memiliki risiko signifikan dan reward atas kepemilikan barang, dan pelanggan telah menerima aset tersebut.

Menurut Komite Standar Akuntansi Pemerintahan (2014) tentang Akuntansi Piutang Berbasis Akrual, pengakuan piutang yang berasal dari pendapatan negara, didahului dengan pengakuan terhadap pendapatan yang mempengaruhi piutang tersebut. Pengakuan piutang berdasarkan pungutan dapat diakui sebagai piutang ketika telah diterbitkan surat ketetapan, dan/atau telah diterbitkan surat penagihan dan telah dilaksanakan penagihan.

Bagi perusahaan di sektor privat, pengelolaan piutang yang baik merupakan hal yang penting. Faktor utama yang menentukan dalam pengelolaan piutang adalah kebijakan kredit. Menurut Weston, Besley, \& Eugene F. Brigham (1996) kebijakan kredit terdiri dari empat variabel, yaitu standar kredit, periode kredit, kebijakan penagihan, dan fungsi pemantauan. Standar Kredit yaitu terkait dengan kemampuan keuangan minimum dan kelayakan kredit yang disyaratkan atas pembelian secara kredit dan berapa jumlah kredit yang tersedia untuk masing-masing 
pelanggan. Periode kredit, termasuk ketentuan dari penjualan secara kredit seperti jangka waktu yang diberikan kepada pembeli untuk membayar pembelian mereka, serta apakah ada potongan yang diberikan untuk pembayaran di awal, dan lainnya. Kebijakan penagihan, terkait dengan prosedur yang digunakan dalam penagihan piutang yang telah jatuh tempo. Fungsi pemantauan merupakan evaluasi berkala atas piutang dan pola pembayaran pelanggan untuk memastikan kebijakan kredit dikelola dengan benar dan untuk mengetahui apakah perlu dilakukan perubahan dalam kebijakan kredit.

Penetapan standar kredit memerlukan pengukuran atas kualitas kredit di mana hal ini terkait dengan kemungkinan gagal bayar dari pelanggan. Metode untuk mengukur kualitas kredit ini berhubungan dengan evaluasi atas lima faktor penting dalam menentukan kelayakan kredit pelanggan. Lima faktor yang sering disebut dengan $5 \mathrm{C}$ tersebut adalah character, capacity, capital, collateral, dan conditions. Character terkait dengan kemungkinan pelanggan akan membayar kewajibannya. Kredit manajer meyakini bahwa karakter pelanggan merupakan hal yang paling penting dalam evaluasi kredit, namun untuk menentukan apakah pelanggan akan diberikan kredit atau tidak yang sangat diperlukan adalah catatan riwayat kredit (reputasi) pelanggan. Capacity merupakan pengukuran atas kemampuan pelanggan dalam menghasilkan kas yang cukup untuk melakukan pembayaran. Hal ini dapat diukur antara lain melalui catatan riwayat pelanggan dan metode bisnis, serta untuk pelanggan berbentuk badan usaha dapat didukung dengan observasi fisik atas pabrik atau toko milik perusahaan tersebut. Capital diukur oleh kondisi keuangan umum dari pelanggan yang ditunjukkan oleh analisis laporan keuangan. Collateral merupakan aset yang diberikan sebagai jaminan untuk mendapatkan kredit. Conditions mengacu kepada tren ekonomi secara umum dan perkembangan khusus dalam suatu area tertentu atau sektor ekonomi yang mempengaruhi kemampuan pelanggan untuk menyelesaikan kewajibannya.

Teori yang mendasari penelitian ini adalah teori New Public Management (NPM) yang diperkenalkan oleh Christopher Hood pada tahun 1991. Teori ini merupakan konsep manajemen publik baru yang menekankan perubahan perilaku dalam penyelenggaraan pemerintahan menjadi lebih efektif dan efisien. Menurut Hood (1991), NPM memiliki tujuh unsur utama, yaitu manajemen profesional di sektor publik, adanya standar pengukuran kinerja yang jelas, penekanan yang lebih besar terhadap pengendalian output, pemecahan unit-unit kerja di sektor publik, persaingan yang lebih besar di sektor publik, penekanan pada corak praktik manajemen sektor swasta ke dalam sektor publik, dan penekanan yang lebih besar pada disiplin dan penghematan dalam penggunaan sumber daya. Fokus dari New Public Management adalah manajemen sektor publik yang berorientasi pada kinerja, bukan pada kebijakan. Hal ini menimbulkan konsekuensi yang antara lain adalah pemerintah dituntut untuk melakukan efisiensi, pengurangan biaya, dan kompetisi tender (Mardiasmo, 2018).

\section{METODE}

Menurut Yin (2009) ketika pertanyaan penelitian perlu untuk menjelaskan beberapa keadaan yang terjadi, metode studi kasus akan semakin relevan. Dengan metode studi kasus peneliti dapat memperoleh karakteristik yang holistic dan berarti dari kejadian nyata, sebagai salah satu contohnya adalah proses organisasional dan manajerial. Sehingga pendekatan studi kasus merupakan metode yang dipilih dan digunakan untuk menjawab pertanyaan penelitian ini.

Penelitian ini menggunakan pendekatan kualitatif, yaitu pendekatan untuk menggali dan memahami makna dari suatu individu atau kelompok terkait masalah sosial atau kemanusiaan (Creswell, 2014). Menurut Moleong (n.d) dalam Arikunto (2010) 
penelitian kualitatif harus memenuhi sebelas karakteristik, yaitu; latar alamiah, manusia sebagai alat, metode kualitatif, analisis data secara induktif, teori dasar, deskriptif, lebih mementingkan proses daripada hasil, adanya batas yang ditentukan oleh fokus, adanya kriteria khusus untuk keabsahan data, desain yang bersifat sementara, dan hasil penelitian dirundingkan dan disepakati bersama.

Data yang dikumpulkan dalam penelitian ini adalah data primer, yaitu data yang diperoleh untuk penelitian dari tempat sebenarnya peristiwa terjadi dan data sekunder yang merupakan data yang diperoleh dari sumber-sumber yang telah tersedia (Sekaran, 2003). Pengumpulan data pada penelitian kualitatif menurut Creswell (2014) terdiri dari observasi, wawancara, dokumen dan materi audio dan visual. Instrumen pengumpulan data pada penelitian ini adalah wawancara dan studi dokumen. Tahapan wawancara menurut Wilkinson \& Birmingham (2003) diawali dengan membuat konsep wawancara, mengarahkan pertanyaan, memilih interviewee, melaksanakan wawancara, kemudian menganalisis data. Wawancara mendalam dengan menggunakan pertanyaan terbuka dilakukan kepada seorang pejabat dan tiga orang staf pelaksana pada Subdirektorat Penanganan Biaya Hak Penggunaan Frekuensi Radio. Dokumentasi dilakukan dengan mengumpulkan dokumen terkait pengelolaan piutang PNBP BHP Frekuensi Radio. Dokumen berupa peraturanperaturan yang berlaku terkait piutang PNBP BHP Frekuensi Radio dan informasi terpublikasi pada instansi terkait.

Analisis data pada penelitian ini menggunakan analisis deskriptif. Menurut Whitney (n.d) dalam Krishnarao (1961), metode deskriptif adalah pencarian fakta dengan interpretasi. Analisis dilakukan setelah data dikumpulkan. Hasil dari studi dokumen dan wawancara penelitian dibandingkan dan dideskripsikan untuk dapat menjawab masalah penelitian.

PNBP pada Kementerian Kominfo salah satunya berasal dari BHP Frekuensi Radio atas Izin Pita Frekuensi Radio (IPFR) dan Izin Stasiun Radio (ISR). Penelitian dilakukan atas pengelolaan piutang PNBP BHP Frekuensi Radio pada Direktorat Jenderal SDPPI Kementerian Kominfo RI dimana porsi terbesar piutang PNBP dan piutang tak tertagih berasal. Pengelolaan piutang ini terdapat pada Direktorat Operasi Sumber Daya di bawah Direktorat Jenderal SDPPI Kementerian Kominfo, sehingga peneliti memilih unit kerja tersebut sebagai unit analisa untuk menjawab pertanyaan penelitian.

Layanan perizinan dilaksanakan oleh Subdirektorat Pelayanan Spektrum Dinas Tetap Bergerak Darat (DTBD) dan Subdirektorat Pelayanan Spektrum Non Dinas Tetap Bergerak Darat (Non DTBD) pada Direktorat Operasi Sumber Daya. Untuk penagihan, pelimpahan piutang dan penghapusan piutang dilaksanakan oleh Subdirektorat Penanganan BHP Frekuensi Radio, sedangkan penerimaannya pembayaran oleh Bagian Keuangan Direktorat Jenderal SDPPI. Untuk pembayaran BHP Frekuensi Radio dilakukan melalui rekening bendahara penerima dengan sistem pembayaran otomatis (host to host payment gateway) pada bank yang ditunjuk oleh Direktorat Jenderal.

\section{HASIL DAN PEMBAHASAN}

Berdasar rumusan masalah pada penelitian, dilakukan analisis atas pengelolaan piutang PNBP pada Kementerian Kominfo. Dari hasil studi dokumen dan wawancara yang dilakukan, diketahui bahwa pengelolaan piutang PNBP telah menggunakan sistem informasi berbasis teknologi yang dapat membantu meningkatkan efisiensi, namun untuk beberapa kasus masih harus dilakukan pemutakhiran secara manual. Pada sektor bisnis, sistem terkomputerisasi digunakan dalam berbagai fungsi bisnisnya dari pencatatan penjualan, penagihan, penerimaan pembayaran, juga dapat digunakan untuk memberikan peringatan atas tagihan yang 
telah jatuh tempo dan tindakan yang diambil kemudian atas tagihan yang telah jatuh tempo tersebut. Penggunaan sistem pada umumnya juga dapat memberikan informasi atas riwayat pembayaran setiap pelanggan, sehingga dapat membantu pengambilan keputusan dalam menetapkan kebijakan kredit yang layak bagi pelanggannya. Pada Direktorat Operasi Sumber Daya, sistem informasi berbasis teknologi telah digunakan dalam setiap fungsinya. Namun Direktorat belum menggunakan secara optimal data yang terdapat pada sistem tersebut. Data yang tersedia pada database sistem seharusnya dapat digunakan untuk menjadi acuan dalam proses pemberian izin, salah satunya adalah data riwayat pembayaran dari setiap wajib bayar, untuk mencegah pemberian izin kepada pemohon yang pernah mengalami kesulitan dalam pembayaran tagihan.

Tahapan proses perizinan dilakukan melalui sistem pelayanan Online Single Submission (OSS). Dalam layanan pemberian izin, satuan kerja telah melaksanakan sistem seleksi atau lelang untuk pemberian IPFR, yang menunjukkan adanya mekanisme pasar dan persaingan dalam sektor publik, namun untuk pemberian ISR mekanisme seleksi ini belum dilakukan. Untuk pengajuan ISR dilakukan verifikasi, pengecekan administrasi dengan memeriksa dokumen permohonan juga memeriksa apakah pemohon masih memiliki kewajiban BHP Frekuensi Radio yang masih terutang. Direktorat Operasi Sumber Daya belum melakukan evaluasi atas beberapa faktor penting dalam menentukan kelayakan pemohon ISR untuk mencegah piutang bermasalah di kemudian hari, seperti yang umum dilakukan oleh perusahaan yang melakukan penjualan secara kredit. Perbankan atau perusahaan yang melakukan penjualan secara kredit biasanya melakukan evaluasi terkait lima faktor (5C). Evaluasi atas faktor-faktor tersebut bertujuan untuk mengurangi risiko piutang yang tidak terbayar. Untuk faktor character, Direktorat tidak melakukan pemeriksaan atas riwayat pembayaran pemohon di waktu lampau. Dari hasil wawancara, pemeriksaan atas pemohon yang dilakukan hanya sampai kepada apakah pemohon ISR masih memiliki kewajiban BHP Frekuensi Radio yang masih terutang. Sedangkan evaluasi atas reputasi atau riwayat pembayaran dari pemohon tidak dilakukan, sehingga tidak diketahui apakah pernah terjadi kesulitan dalam penagihan atas kewajiban pemohon di waktu yang lampau. Untuk pengecekan atas faktor character dan capacity, Direktorat dapat memanfaatkan data riwayat pembayaran dari sistem informasi yang sudah ada, untuk dapat dijadikan pertimbangan untuk mengambil keputusan dalam pemberian izin ke depannya. Faktor collateral di mana aset diberikan sebagai jaminan untuk mendapatkan kredit, dalam hal ini pemenang seleksi atas IPFR wajib menyerahkan jaminan komitmen pembayaran biaya IPFR tahunan, namun untuk wajib bayar ISR keharusan untuk menyerahkan jaminan ini tidak ada. Jaminan ini akan dicairkan jika sampai pada tanggal jatuh tempo pembayaran BHP IPFR wajib bayar belum melunasi biaya IPFR tahunannya. Jaminan selain memberikan keamanan jika terjadi masalah dalam pembayaran tagihan, sesuai PMK juga dapat diperhitungkan sebagai pengurang pada pembentukan Penyisihan Piutang Tidak Tertagih, yang berarti dapat mengurangi risiko ketidaktertagihan piutang.

Dalam aktivitas penagihan, penghitungan tagihan dilakukan oleh sistem dan rincian tagihan pembayaran BHP Frekuensi Radio dapat diakses oleh Wajib Bayar melalui sistem perizinan elektronik. Nilai tagihan yang belum dibayarkan setelah jatuh tempo akan tercatat secara otomatis pada sistem sebagai piutang. Surat Tagihan (ST) akan diterbitkan jika Wajib Bayar tidak melakukan pembayaran setelah melewati tanggal jatuh tempo pembayaran. Pembayaran kewajiban PNBP yang melewati tanggal jatuh tempo dikenakan denda sebesar $2 \%$ dari tagihan per bulan dan dihitung secara kumulatif setiap bulannya, dengan maksimum denda yang dikenakan selama 24 
bulan. Dalam proses penagihan dan pencatatannya, Direktorat Operasi Sumber Daya menggunakan Sistem Informasi Manajemen Spektrum SDPPI (SIMS). Sistem ini melakukan penghitungan atas nilai tagihan dan juga atas denda jika wajib bayar terlambat melunasi kewajibannya.

Wajib Bayar dapat memperoleh rincian tagihan melalui sistem perizinan elektronik yang diterbitkan 60 hari sebelum jatuh tempo pembayaran, namun sesuai Standar Operasional Prosedur (SOP) yang ada, petugas layanan Unit Pelaksana Teknis (UPT) di daerah harus tetap melakukan upaya penagihan kepada Wajib Bayar dan mengusahakan agar wajib bayar menerima rincian tagihan atau surat tagihan yang diterbitkan. UPT juga wajib untuk mengirimkan laporan tertulis atas rekap hasil distribusi SPP Baru, Rincian Tagihan, Surat Tagihan dan Surat Pencabutan ISR kepada wajib bayar dengan standar waktu yang telah ditentukan dalam SOP. Dari sini dapat dilihat bahwa Direktorat Operasi Sumber Daya telah melakukan usaha secara maksimal untuk mencegah timbulnya piutang dan mengupayakan penurunan piutang yang sudah terbentuk. Direktorat Operasi Sumber Daya memiliki standar pengukuran kinerja yang jelas, dengan menjadikan persentase pencapaian PNBP sebagai indikator kinerja pada Perjanjian Kinerja, namun atas usaha terkait fungsi penanganan piutang, termasuk dalam pencegahan dan pengurangan piutang, belum dibuatkan indikator dan target kinerjanya. Hal ini akan menyulitkan dalam pengukuran keberhasilan atas aktivitas yang telah dilakukan dan atas pemanfaatan sumber daya yang telah digunakan, sehingga ke depannya akan sulit untuk menentukan aktivitas yang paling baik untuk mengurangi dan mencegah timbulnya piutang.

Pembayaran tagihan dilakukan secara host-to-host melalui bank yang telah ditunjuk, dan secara non host-to-host. Pembayaran non host-to-host ini dilakukan oleh instansi pemerintah yang pembayarannya dilakukan melalui Kantor Pusat Perbendaharaan Negara (KPPN) dan pembayaran dari Kantor
Pelayanan Kekayaan Negara dan Lelang (KPKNL) atas penyetoran piutang negara yang telah dilimpahkan. Setiap pembayaran atas piutang yang dilakukan secara host-tohost akan langsung terhubung dengan SIMS dan secara otomatis akan dimutakhirkan oleh sistem. Sedangkan untuk pembayaran nonhost-to-host pemutakhiran dilakukan oleh staf pelaksana secara manual. Aktivitas penerimaan pembayaran tagihan yang dilakukan baik secara host-to-host maupun pembayaran ke rekening non-host-to-host membantu dalam mengurangi akses petugas kepada fisik kas yang diterima, sehingga kemungkinan penyalahgunaan kas dapat dikurangi. Pemisahan tugas juga dilakukan antara Bendahara Penerimaan dan pegawai yang memaintain data piutang. Pemisahan fungsi ini dapat mengurangi kemungkinan pegawai melakukan kesalahan ataupun kecurangan. Dari segi pencatatan yang harus diperhatikan adalah pelunasan tagihan dari wajib bayar ke KPKNL dimutakhirkan pada sistem secara manual oleh staf pelaksana, sementara rekonsiliasi antara Direktorat Operasi Sumber Daya dan KPKNL dilaksanakan namun tidak secara terjadwal. Hal ini dapat menyebabkan nilai piutang yang kurang akurat pada saat pelaporan.

Pembentukan penyisihan piutang tidak tertagih dihitung berdasarkan kualitas piutang yang dikategorikan berdasarkan Peraturan Menteri Keuangan (PMK) dan Pedoman Menteri Komunikasi dan Informatika. Penghitungan penyisihan piutang tidak tertagih dilakukan dengan menggunakan Modul Piutang BHP Frekuensi Radio yang terdapat pada SIMS, sehingga kemungkinan kesalahan dalam penghitungan dapat dikurangi. Data piutang dari modul ini menjadi laporan tersendiri untuk penyisihan piutang tidak tertagih. Laporan ini divalidasi oleh Direktorat teknis dan disampaikan ke bagian Keuangan untuk dicatat pada aplikasi Sistem Akuntansi Berbasis Akrual (SAIBA). Nilai penyisihan piutang tidak tertagih yang terbentuk dapat berkurang jika setiap izin yang diterbitkan disertai dengan jaminan yang telah disetujui oleh Menteri Keuangan, 
namun praktiknya saat ini tidak seluruh izin yang terbit disyaratkan untuk memberikan jaminan.

Aktivitas pelimpahan piutang dimulai ketika muncul status 'revoke' pada sistem. Revoke (pencabutan izin) untuk ISR dilakukan satu bulan setelah ST Terakhir diberikan kepada wajib bayar. ST terakhir diberikan kepada pemilik ISR jika dalam waktu tiga bulan dari jatuh tempo pembayaran tidak melunasi tagihan. Pencabutan IPFR dilakukan jika sampai bulan ke 24 sejak tanggal jatuh tempo tagihan belum dilakukan pembayaran. Selama periode sebelum izin dicabut, denda akan dihitung secara akumulasi sebesar $2 \%$ per bulan. Dengan jangka waktu yang lebih panjang, IPFR yang umumnya memiliki nilai pokok tagihan yang besar tentunya akan menanggung denda yang juga besar jika dihitung dalam waktu 24 bulan. Dalam waktu 24 bulan sampai dengan izin dicabut, memungkinkan terbit rincian tagihan tahunan untuk tahun berjalan. Nilai tagihan tahun berjalan beserta dendanya akan menambah nilai tagihan yang harus dilunasi oleh wajib bayar. Hal ini menyebabkan nilai piutang dan penyisihan piutang tidak tertagih semakin meningkat jika wajib bayar tidak juga melakukan pelunasan atas tagihannya.

Aktivitas pelimpahan piutang telah memiliki SOP yang di dalamnya sudah menetapkan mutu baku waktu untuk proses pelimpahan dari persiapan di Direktorat sampai penyerahan ke KPKNL. Dalam praktiknya, jika satu aplikasi perizinan dari satu wajib bayar masuk status 'revoke', maka akan dikumpulkan dulu dengan aplikasi lainnya milik wajib bayar tersebut yang juga telah berstatus 'revoke'. Hal ini akan memperlambat proses pelimpahan ke KPKNL atas beberapa wajib bayar dan waktu pemrosesan tidak sesuai dengan yang sudah ditetapkan pada SOP. Pelimpahan piutang ke KPKNL tidak akan mengurangi nilai piutang dan penyisihan piutang tidak tertagih Kementerian Kominfo, karena piutang tersebut tetap dicatat sebagai piutang PNBP BHP Frekuensi Kementerian Kominfo.

Terkait salah satu unsur pada teori NPM yang menekankan corak praktik manajemen sektor swasta ke dalam sektor publik, pada sektor swasta terdapat beberapa mekanisme yang dapat dilakukan oleh perusahaan untuk mengurangi piutang macetnya, antara lain dengan melakukan factoring atas piutang macetnya kepada pihak lain. Pada sektor pemerintahan, piutang macet yang terdapat pada Kementerian dan Lembaga hanya dapat diserahkan ke KPKNL untuk pengurusannya.

Untuk pembahasan atas aktivitas penghapusan piutang pada penelitian ini hanya terbatas pada penghapusan piutang secara bersyarat, yaitu penghapusan piutang negara dari pembukuan tanpa menghapus hak tagih negara. Penghapusan piutang secara bersyarat menurut Peraturan Pemerintah, dapat dilakukan setelah piutang diurus secara optimal oleh KPKNL dan dinyatakan sebagai Piutang Sementara Belum Dapat diTagih (PSBDT). Penetapan PSBDT ini kemudian menjadi dasar bagi Kementerian untuk membuat surat pengajuan usul penghapusan. Peraturan tidak mengatur jangka waktu pengurusan piutang yang optimal sampai dapat ditetapkan sebagai PSBDT, sehingga nilai piutang dan penyisihannya tersebut akan cenderung tetap dalam jangka waktu yang cukup lama, terutama atas piutang dengan nilai yang cukup signifikan, karena surat usulan pengajuan penghapusan tidak dapat diproses sampai ditetapkan sebagai PSBDT. Dari hasil wawancara juga diketahui bahwa Direktorat telah menerima beberapa surat PSBDT di tahun 2016, 2017 dan 2018 yang baru diproses surat pengajuan usul penghapusannya di tahun 2019. Dalam menindaklanjuti PSBDT yang telah diterima, staf pelaksana menunggu arahan dari atasan karena belum adanya petunjuk teknis ataupun SOP untuk menjadi panduan dalam melakukan proses pengajuan penghapusan piutang. Pengajuan penghapusan piutang bersyarat yang tidak segera diproses setelah menerima surat PSBDT akan berpotensi 
menyebabkan nilai piutang yang ditampilkan pada laporan keuangan menjadi kurang realistis.

\section{KESIMPULAN}

Berdasarkan temuan dan analisis data yang telah dilakukan, maka kesimpulan yang dapat ditarik terkait pengelolaan piutang PNBP yang berpotensi menyebabkan tingginya nilai piutang dan penyisihan piutang tidak tertagih pada Kementerian Kominfo terletak pada evaluasi yang kurang komprehensif dalam pemberian ISR untuk mencegah timbulnya piutang yang bermasalah di kemudian hari. Hal berikutnya terletak pada fungsi penagihan yang belum memiliki indikator dan target yang terukur terkait dengan piutang yang dapat ditagih oleh unit kerja, sehingga sulit untuk mengukur tingkat keberhasilan atas aktivitas pengelolaan piutang yang telah dilaksanakan. Selain kedua hal tersebut, nilai piutang PNBP juga berpotensi kurang akurat dikarenakan belum adanya SOP pengajuan penghapusan piutang setelah penetapan PSBDT serta rekonsiliasi yang belum rutin dan terjadwal dengan KPKNL atas pelunasan piutang PNBP.

Keterbatasan penelitian ini antara lain terletak pada penggunaan instrumen penelitian dengan pendekatan kualitatif Karenanya, peneliti merekomendasikan penelitian selanjutnya untuk menggunakan instrumen penelitian yang lebih variatif serta menggunakan pendekatan kuantitatif untuk mengukur besarnya pengaruh faktor-faktor penyebab terhadap tingginya nilai piutang PNBP BHP Frekuensi tersebut.

\section{DAFTAR PUSTAKA}

Arens, A. A., Elder, R. J., \& Beasley, M. S. (2012). Auditing and Assurance Services (14th ed.). Prentice Hall.

Arikunto, S. (2010). Prosedur Penelitian Suatu Pendekatan Praktek. Jakarta: Rineka Cipta.
Creswell, J. W. (2014). Research Design Qualitative, Quantitative, and Mixed Methods Approaches.

Donald E. Kieso PhD, C., Jerry J. Weygandt $\mathrm{PhD}, \mathrm{C} .$, \& Terry D. Warfield, P. (2018). Intermediate Accounting: IFRS Edition (3rd Editio). WILEY.

Ellet, W. (2007). Case Study Handbook. Boston, Massachusetts: Harvard Business Scholl Press.

Hood, C. (1991). A Public Management For All Seasons, 69, 3-20. https://doi.org/10.1111/j.14679299.1991.tb00779.x

Komite Standar Akuntansi Pemerintahan. (2014). Buletin Teknis Standar Akuntansi Pemerintahan Nomor 16 : Akuntansi Piutang Berbasis Akrual.

Krishnarao, B. (1961). The Descriptive Method in Social Research. Sociological Bulletin, 10(2), 46-52. Retrieved from http://www.jstor.org/stable/42864589

Mardiasmo. (2018). Akuntansi Sektor Publik. (Mardiasmo, Ed.). Yogyakarta: ANDI.

Meriam, I. L., Achsani, N. A., \& Novianti, T. (2017). Receivable Management Performance Measurement Tool and Factors Affecting Account Receivable Performance. International Journal of Science and Research (IJSR), 6(10), 1169-1177. https://doi.org/10.21275/ART2017707 2

Nebugri, H., \& Senzu, E. T. (2017). Account receivable management across Industrial sectors in Ghana; analyzing the economic effectiveness and efficiency.

Presiden Republik Indonesia. (2010). Peraturan Pemerintah Republik 
Indonesia Nomor 71 Tahun 2010

tentang Standar Akuntansi

Pemerintahan.

Republik Indonesia. (2004) Undang-Undang Republik Indonesia Nomor 1 Tahun 2004 Tentang Perbendaharaan Negara.

Romney, M. B., \& Steinbart, P. J. (2015). Accounting Information Systems (13th ed.). Pearson.

Sekaran, U. (2003). Research methods for business (4th edition). New York, USA: John Wiley \& Sons (Vol. 65). John Wiley \& Sons, Inc. https://doi.org/10.1017/CBO97811074 15324.004

Taroreh, J. R., Warongan, J. D. ., \& Runtu, T. (2016). Evaluasi Penerapan Sistem Pengendalian Internal Piutang Pada Pt Mandiri Tunas Finance Cabang Manado. Jurnal Riset Ekonomi, Manajemen, Bisnis Dan Akuntansi, 4(3), 125-134.

Weston, J. F., Besley, S., \& Eugene F. Brigham. (1996). Essentials of Managerial Finance (11th ed.). Dryden Press.

Wilkinson, D., \& Birmingham, P. (2003). Using Research Instruments: A Guide for Researchers. London: RoutledgeFalmer.

Yin, R. K. (2009). Case Study Research Design and Methods (4th ed.). SAGE Publications, Inc. 